\title{
Evaluation of quality characteristics and storage stability of mixed fruit jam
}

\author{
1, ${ }^{*}$ Rana M.S., ${ }^{1}$ Yeasmin F., ${ }^{2}$ Khan M.J. and ${ }^{3}$ Riad M.H. \\ ${ }^{I}$ Department of Agro Product Processing Technology, Jashore University of Science and Technology, \\ Jashore-7408, Bangladesh \\ ${ }^{2}$ Department of Chemical and Food Engineering, Dhaka University of Engineering and Technology, \\ Gazipur-1707, Bangladesh \\ ${ }^{3}$ Department of Food Technology and Rural Industries, Bangladesh Agricultural University, Mymensingh- \\ 2202, Bangladesh
}

\section{Article history: \\ Received: 16 July 2020 \\ Received in revised form: 9 August 2020 \\ Accepted: 1 September 2020 Available Online: 5 \\ December 2020}

\section{Keywords:}

Jam,

Physicochemical properties,

Sensory evaluation,

Storage stability

\section{DOI:}

https://doi.org/10.26656/fr.2017.5(1).365

\begin{abstract}
Diversification of food is the key factor for enhancing physicochemical properties, nutritional status and consumer satisfaction. Hence, mixed fruits jam was developed from coconut and pineapple pulps in varied ratios (1:1, 3:1 and 1:3). Moisture, lipid, protein, fiber, ash and total carbohydrate contents of different jam samples varied significantly $(\mathrm{p} \leq 0.05)$ and found values in the ranges $26.78-29.15 \%, 4.12-10.81 \%, 0.56-1.13 \%, 1.51-$ $3.12 \%, 0.30-0.37 \%$ and $62.69-67.91 \%$ respectively. Storage stability of the jam samples was analyzed for 6 months keeping under refrigerated $\left(4^{\circ} \mathrm{C}\right)$ and room $\left(30^{\circ} \mathrm{C}\right)$ temperatures. Physicochemical properties such as total soluble solids, acidity, $\mathrm{pH}$ and reducing sugar content were evaluated at 2-months intervals. The parameters were changed variedly due to compositional variances, packaging materials and storage temperatures. Total soluble solids, acidity and reducing sugar content increased gradually while $\mathrm{pH}$ declined upon extension of storage period. Sensory properties for color, taste, flavor, texture and overall acceptability of jam samples were tested where sample with pineapple and coconut in the ratio 3:1 showed the best result than others. Samples were also analyzed for yeast and mold count at the end of the storage period and positive result was found in case of samples packed in plastic containers kept under room temperature. The study yields diversified jam samples with better nutritional and sensory properties with satisfactory shelf life.
\end{abstract}

\section{Introduction}

Jam is a popular food item due to its low cost and high organoleptic profiles (Gałkowska et al., 2010). Jam should contain approximately $67-68 \%$ total soluble solids (TSS) along with 45\% fruit pulp at least, while according to the 'Codex Alimentarius Commission' jam need to contain TSS approximately greater than $65 \%$ (Baker et al., 2005). It tends to apprehend shape, but normally less firm compared to jelly. Jam has prolonged shelf life so that it can be available round the year. Production of jam requires ingredients (fruit pulp, acid, pectin and sugar) of correct quantities for having desired finished product. Raw material quality and process of manufacturing are the exponents to the quality of finished goods (Nindo et al., 2005). Citric acid is considered necessary to create a network between sugar and pectin, which is needed to form jam. Sugar functions as a dehydrating agent that makes a closer connection between molecules (Suutarinen, 2002). Pectin is purified polysaccharide generally extract from the peel of citrus fruits. Pectin is a thickening agent since it brings changes in the texture and flow behavior of the finished product (Javanmard and Endan, 2010).

Coconut palm is one of the economically important trees. Several traditional foods are processed from coconut due to its admissibility, quality and mercantile viability (Kumar et al., 2007). The major fatty acid of coconut is Lauric acid which has antibacterial, antiviral and antiprotozoal functions. Coconut pulp consists of soft flesh and sweet redolent juice. It contains a high content of minerals as iron, phosphorus and zinc. Coconut pulp can be used to process food preserves such as jam. 
Pineapple is popular torrid regional fruit under the family Bromeliaceae (Coppens et al., 2003) which is consumed as fresh, juice, candies, cooked foods and incorporated with desserts (Ackom and Tono-Debrah, 2012). It is a rich principium of dietary fiber, minerals and vitamins, particularly manganese and vitamin $\mathrm{C}$ (Ackom and Tono-Debrah, 2012). Moreover, it provides an array of organoleptic attributes like color, mouthfeel, flavor, texture etc. which give the delectation of consumption (Othman, 2011).

Sensory science is a discipline to measure and evaluate people's appeal to products perceived through the 5 senses such as sight, smell, touch, taste and sound. In food product development, sensory evaluation not only provides a clear understanding of consumer acceptability but also reduces the risk of product failure.

Mixed jam associates the characteristics of two or more fruits with better nutritional status and excellent sensory profile. The purpose of the study is to utilize coconut pulp in association with pineapple pulp to fulfill the following objectives: to prepare mixed fruits jam from coconut and pineapple, to evaluate the physicochemical properties and sensory attributes of the prepared mixed fruits jam, and to analyze the storage stability of mixed fruit jam under room and refrigerated conditions using different packaging materials.

\section{Materials and methods}

\subsection{Collection of raw materials}

The experimental samples coconut, pineapple (Honey Queen), sugar, citric acid and pectin were collected from Mymensingh and Jashore, Bangladesh regional market. Analytical grade reagents were used for testing.

\subsection{Formulation of mixed fruits jam}

Three mixed fruit jam samples $\mathrm{M}, \mathrm{CP}$ and $\mathrm{PC}$ were prepared with different fruit pulp combinations as presented in Table 1.

Table 1. Mixed fruit jam formulations

\begin{tabular}{ccc}
\hline \multirow{2}{*}{ Sample } & \multicolumn{2}{c}{ Fruit pulp concentration } \\
\cline { 2 - 3 } & \% Coconut & \% Pineapple \\
\hline M & 50 & 50 \\
PC & 25 & 75 \\
CP & 75 & 25 \\
\hline
\end{tabular}

\subsection{Preparation of mixed fruits jam}

At first Fruits pulp were mixed in standardized proportions. $45 \%$ fruits pulp, 55\% sugar along with $1 \%$ pectin were mixed in a stainless-steel pan. The mixture was heated and stirred under a low flame gas stove. 1\% citric acid was added when the mixture attained TSS to $60^{\circ}$ Brix. Heating was postponed when TSS of the concentrate reached to $67-68^{\circ}$ Brix. Finally, the hot finished good was filled in sterilized glass and plastic containers.

\subsection{Proximate composition analysis of fruits and jam samples}

Moisture, ash, fat, protein and fiber content of fresh fruits and prepared jam samples were analyzed as per AOAC (2016) method. Total carbohydrate content was calculated according to Pearson (1970), i.e. total carbohydrate $=100-$ (protein + fat + ash + moisture $)$. Triplicate determination was followed and outcomes were represented as the mean \pm standard deviation.

\subsection{Storage stability of jam}

Jam samples were packed in glass and plastic containers and total soluble solids (TSS), acidity, $\mathrm{pH}$ and reducing sugar contents were tested for a period of 6 months at 2 months intervals keeping under room $\left(30^{\circ} \mathrm{C}\right)$ and refrigeration $\left(4^{\circ} \mathrm{C}\right)$ temperature. TSS was measured by digital refractometer (Model: DR 301-95, A. KRUSS Optronic Company, Germany), $\mathrm{pH}$ was tested using $\mathrm{pH}$ meter (Model: PH500, CLEAN Instruments Co. Ltd., Shanghai, China), titratable acidity and reducing sugar of jam was analyzed according to AOAC (2016) method.

\subsection{Yeast and mold count}

Colony forming units (CFU) of yeast and mold were counted using standard plate count (SPC) method. Potato Dextrose Agar was used as media and plates were decorated by the pour plate method. Distilled water was dispensed $9 \mathrm{~mL}$ into 10 tubes and sterilized in an autoclave. Jam samples were used in several dilutions to have CFU in the range 20-200. The sterilized potato dextrose agar was poured on Petri dishes along with $10 \%$ tartaric acid. Then pouring was done with sample of several dilutions and gently mixed for ensuring that the medium covered the plate evenly. After that the agar gel was allowed to solidify and the petri dishes were sealed with lids. The plates were then incubated at inverted position at $30^{\circ} \mathrm{C}$ for $72 \mathrm{hrs}$.

\subsection{Organoleptic test}

The organoleptic properties of all samples for color, flavor, taste and overall acceptability were analyzed by 9 -point hedonic rating test using a panel team consisting of 10 trained members (Begum et al., 2018). 


\subsection{Statistical analysis}

The obtained data were analyzed using Microsoft Office Excel 2013 for standard deviation, single factor and two factor Analysis of Variance (ANOVA). Fisher's LSD Multiple Comparison Test procedures of the Method of Statistical (MSTAT) system was performed to determine the significant difference among the various samples by taking $5 \%$ level of significance according to Gomez and Gomez (1984).

\section{Results and discussion}

\subsection{Proximate composition of coconut and pineapple}

Proximate composition of coconut and pineapple are represented in Table 2.

The highest moisture and carbohydrate content were found in the case of pineapple $(86.28 \%$ and $12.61 \%$ ) than coconut $(51.93 \%$ and $10.47 \%)$. On the contrary, coconut contained highest protein $(3.24 \%)$, fat $(33.45 \%)$ and ash $(0.89 \%)$ content than pineapple $(0.53 \%, 0.19 \%$ and $0.47 \%$ ). Nutritional status of pineapple and coconut is nearly similar as proposed by Unaegbu et al. (2016) and Amarasiri et al. (2006) respectively.

\subsection{Proximate composition of mixed fruit jam samples}

Chemical composition of jam samples is represented in Table 3.

The moisture content of the sample PC was higher $(29.15 \%$, ) followed by the sample M $(28.52 \%)$. The lowest moisture content was found in the case of sample CP (26.78\%). Moisture content variations observed might be because of the heating process involved in processing. Water removal during the processing of jam resulted in a change in the concentration of food nutrients (Saka et al., 2007). Moisture content has a greater impact on the shelf life of products (Eke-Ejiofor and Owuno, 2013). Inam et al. (2012) showed moisture content variation of mixed fruit marmalade in the range 26.63-27.71\%, Naeem et al. (2017) in the range 31.23$33.36 \%$ and Mahdi et al. (2019) in the range 3.55$36.86 \%$.

The crude fat percentage of jam samples were in the range $4.12-10.81 \%$, where sample $\mathrm{CP}$ and $\mathrm{PC}$ showed the highest $(10.81 \%)$ and the lowest $(4.12 \%)$ values respectively. The data observed are comparable as claimed by Olugbenga et. al. (2018) for jam processed from a mixture of pineapple, banana and watermelon in the range $0.25-3.85 \%$.

The crude protein content of the sample CP was the highest $(1.13 \%)$, while sample PC gave the lowest value (0.56\%). Naeem et al. (2017) reported crude protein content of different fruit jam samples in the range 0.27$0.41 \%$. Eke-Ejiofor and Owuno (2013) showed protein content of pineapple and jackfruit mixed jam in the range $0.46-0.19 \%$ and Anuradha et al. (2017) claimed protein content of papaya and pineapple jam in the range 5.4$5.41 \%$.

Fiber contents of the mixed fruit jam samples were significantly different from each other. Sample CP had the highest $(3.12 \%)$, while sample PC had the lowest (1.51\%) fiber content. Olugbenga et al. (2018) reported fiber content of jam processed from mixture of pineapple, banana and watermelon in the range 1.25$3.03 \%$. Naeem et al. (2017) reported crude fiber content of different fruit jams in the range $0.09-0.54 \%$.

Ash content of jam samples found in the range 0.30-

Table 2. Proximate composition of coconut and pineapple

\begin{tabular}{lccccc}
\hline \multirow{2}{*}{ Sample } & \multicolumn{5}{c}{ Proximate composition (\%) } \\
\cline { 2 - 6 } & Water & Protein & Fat & Ash & Carbohydrate \\
\hline Coconut & $51.93 \pm 0.18^{\mathrm{b}}$ & $3.24 \pm 0.07^{\mathrm{a}}$ & $33.45 \pm 0.095^{\mathrm{a}}$ & $0.89 \pm 0.031^{\mathrm{a}}$ & $10.47 \pm 0.222^{\mathrm{a}}$ \\
Pineapple & $86.28 \pm 0.132^{\mathrm{a}}$ & $0.53 \pm 0.045^{\mathrm{b}}$ & $0.19 \pm 0.007^{\mathrm{b}}$ & $0.47 \pm 0.015^{\mathrm{b}}$ & $12.61 \pm 0.177^{\mathrm{b}}$ \\
\hline
\end{tabular}

Values are expressed as mean \pm standard deviation of three replicates. Values with the same superscript within column indicates no significant difference $(\mathrm{p}>0.05)$.

Table 3. Proximate composition of jam samples

\begin{tabular}{lccc}
\hline Proximate composition (\%) & \multicolumn{3}{c}{ Jam sample } \\
\cline { 2 - 4 } & \multicolumn{1}{c}{$\mathrm{M}$} & PC & CP \\
\hline Moisture & $28.52 \pm 0.131^{\mathrm{b}}$ & $29.15 \pm 0.192^{\mathrm{a}}$ & $26.78 \pm 0.12^{\mathrm{c}}$ \\
Crude Fat & $7.59 \pm 0.035^{\mathrm{b}}$ & $4.12 \pm 0.04^{\mathrm{c}}$ & $10.81 \pm 0.05^{\mathrm{a}}$ \\
Crude Protein & $0.86 \pm 0.025^{\mathrm{b}}$ & $0.56 \pm 0.015^{\mathrm{c}}$ & $1.13 \pm 0.025^{\mathrm{a}}$ \\
Crude Fiber & $2.31 \pm 0.036^{\mathrm{b}}$ & $1.51 \pm 0.042^{\mathrm{c}}$ & $3.12 \pm 0.035^{\mathrm{a}}$ \\
Ash & $0.34 \pm 0.015^{\mathrm{ab}}$ & $0.30 \pm 0.0159^{\mathrm{b}}$ & $0.37 \pm 0.008^{\mathrm{a}}$ \\
Total Carbohydrate & $62.69 \pm 0.136^{\mathrm{b}}$ & $65.86 \pm 0.208^{\mathrm{a}}$ & $67.91 \pm 0.049^{\mathrm{c}}$ \\
\hline
\end{tabular}

Values are expressed as mean \pm standard deviation of three replicates. Values with the same superscript within row indicates no significant difference $(\mathrm{p}>0.05)$. 
$0.37 \%$. Sample CP had the highest ash content $(0.37 \%)$ followed by the sample M $(0.34 \%)$, while sample PC had the lowest value $(0.30 \%)$. Ash content of different samples is comparable to the works reported by Monika et al. (2018) in the range $0.32-0.34 \%$ and Naeem et al. (2017) in the range $0.12-0.25 \%$.

Sample CP showed the highest carbohydrate content (67.91\%) compared to the sample PC (65.86\%) and sample M (62.69\%). Naeem et al. (2015) reported total carbohydrate content of different fruit jams in the range 65.99-67.65\%, Olugbenga et al. (2018) reported carbohydrate content of jam prepared from a mixture of pineapple, banana and watermelon in the range 70.62$85.32 \%$. So, our found data are correlated with other researchers.

\subsection{Change of physicochemical characteristics of mixed} fruit jam during storage

\subsubsection{Total soluble solids (TSS)}

Primary TSS of sample M, PC, CP were $67.0^{\circ}$ Brix, $67.7^{\circ}$ Brix, $67.5^{\circ}$ Brix which increased to $69^{\circ}$ Brix, $68.9^{\circ}$ Brix, $69^{\circ}$ Brix; and $68.5^{\circ}$ Brix, $68.8^{\circ}$ Brix, $68.7^{\circ}$ Brix when packed in glass container stored under room and refrigeration temperature respectively. Again, TSS increased to $68.9^{\circ} \mathrm{Brix}, 68.7^{\circ} \mathrm{Brix}, 68.8^{\circ} \mathrm{Brix}$; and $68.3^{\circ}$ Brix, $68.4^{\circ}$ Brix, $68.6^{\circ}$ Brix when packed in plastic container stored under room and refrigeration temperature respectively (Figure 1). The possible cause of raising of TSS due to the formation of mono and disaccharides resulted from hydrolysis of polysaccharides (Satkar et al., 2012). An incessant increase in TSS of jam during storage stability evaluation was reported by several workers such as Sindumathi and Amutha (2014) for coconut-based jam, Inam et al. (2012) for mixed fruit marmalade and Patel et al. (2015) for banana - pineapple blended jam.

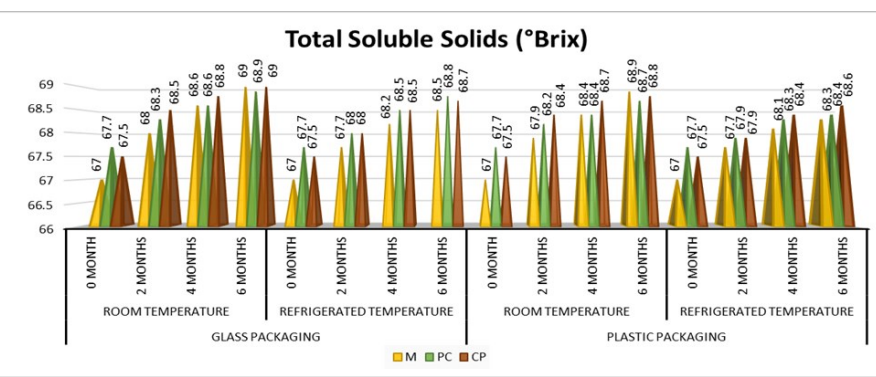

Figure 1. Change of TSS of jam samples during storage

\subsubsection{Acidity}

Initial acidity of sample $\mathrm{M}, \mathrm{PC}, \mathrm{CP}$ were $0.55 \%$, $0.65 \%, 0.53 \%$ which increased to $0.74 \%, 0.85 \%, 0.78 \%$; and $0.68 \%, 0.79 \%, 0.7 \%$ when packed in glass container stored under room and refrigeration temperature respectively. Again, acidity increased to $0.73 \%, 0.85 \%$, $0.78 \%$; and $0.68 \%, 0.79 \%, 0.7 \%$ when packed in plastic container stored under room and refrigeration temperature respectively (Figure 2). The results are comparable to the works of Inam et al. (2012) for mixed fruit marmalade, Sindumathi and Amutha (2014) for coconut-based jam, Hussain and Shakir (2010) for apricot apple mixed fruit jam and Anuradha et al. (2017) for Paniol fruit jam and jelly

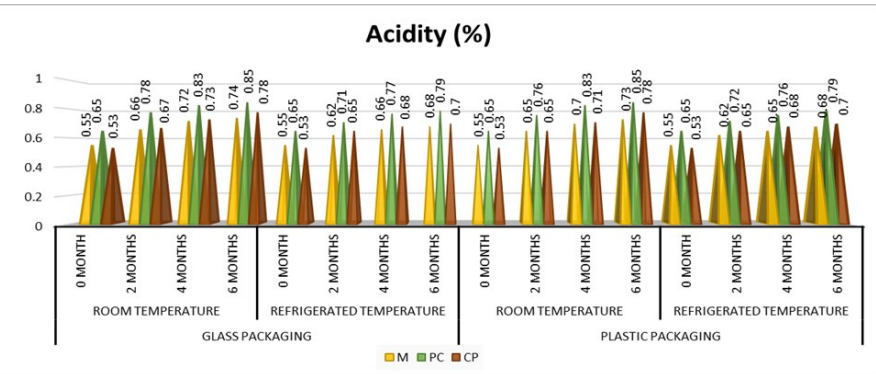

Figure 2. Change of acidity of jam samples during storage

\section{$3.3 .3 \mathrm{pH}$}

Initial $\mathrm{pH}$ of sample M, PC, CP were 2.96, 2.92, 2.97 which decreased to $2.87,2.83,2.85$; and 2.91, 2.85, 2.89 when packed in glass container stored under room and refrigeration temperature respectively. Again, $\mathrm{pH}$ decreased to $2.87,2.83,2.85$; and 2.91, 2.83, 2.89 when packed in plastic container stored under room and refrigeration temperature respectively (Figure 3 ). The outcomes are correlated with the works of Inam et al. (2012) for mixed fruit marmalade, Sindumathi and Amutha (2014) for coconut-based jam.

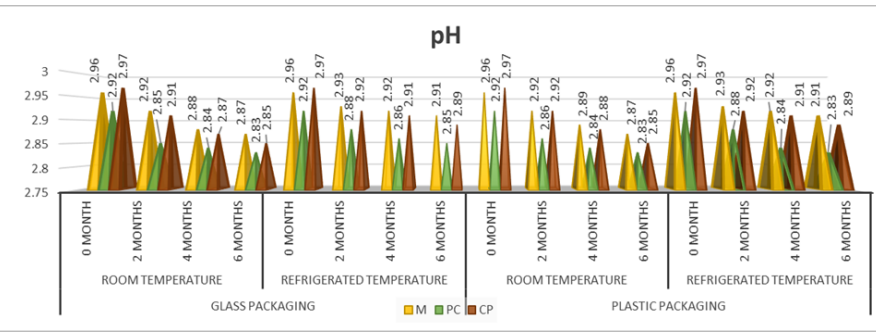

Figure 3. Change of $\mathrm{pH}$ of jam samples during storage

\subsubsection{Reducing sugar}

Reducing sugar quantity of jam samples gradually rise with the prolonged storage period. It was observed that raising of reducing sugar level for the samples stored under refrigerated temperature was considerably lower than the samples of room temperature. Reducing sugar content of the sample M, PC, CP were 16.76 (g/100 g), $16.22(\mathrm{~g} / 100 \mathrm{~g}), 17.1(\mathrm{~g} / 100 \mathrm{~g})$ which increased to 18.12 $(\mathrm{g} / 100 \mathrm{~g}), 18.08(\mathrm{~g} / 100 \mathrm{~g}), 18.13(\mathrm{~g} / 100 \mathrm{~g})$; and 17.8 $(\mathrm{g} / 100 \mathrm{~g}), 18.02(\mathrm{~g} / 100 \mathrm{~g}), 17.95(\mathrm{~g} / 100 \mathrm{~g})$ when packed in glass container stored under room and refrigeration temperature respectively. Again, reducing sugar content increased to $18.06(\mathrm{~g} / 100 \mathrm{~g}), 17.95(\mathrm{~g} / 100 \mathrm{~g}), 18.02$ $(\mathrm{g} / 100 \mathrm{~g})$; and $17.65(\mathrm{~g} / 100 \mathrm{~g}), 17.73(\mathrm{~g} / 100 \mathrm{~g}), 17.86$ $(\mathrm{g} / 100 \mathrm{~g})$ when packed in plastic container stored under room and refrigeration temperature respectively (Figure 4). Similar kind of results was reported by Sindumathi 
and Amutha (2014) for coconut-based jam, Hussain and Shakir (2010) for apricot and apple jam and Vidhya and Narain (2011) for wood apple fruit preserve. Raising of reducing sugar content of jam samples might be because of formation of glucose and fructose resulted from inversion of disaccharides such as sucrose.

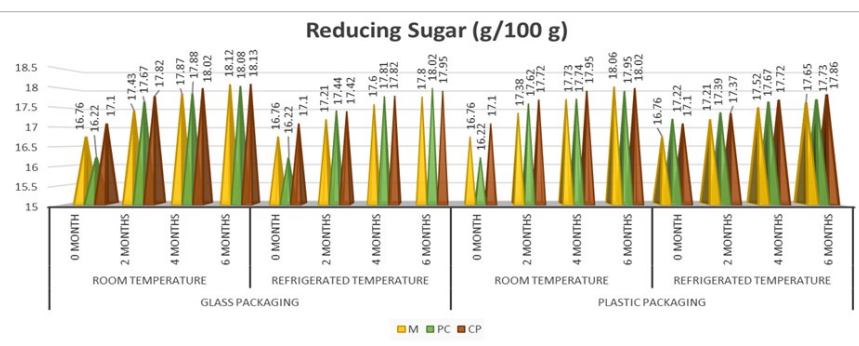

Figure 4. Change of reducing sugar of jam samples during storage

\subsection{Organoleptic test}

There was significant difference in preference of color, flavor, taste and overall acceptability among the different samples as represented in Table 4.

Table 4. Sensory evaluation of jam

\begin{tabular}{lccc}
\hline Proximate & \multicolumn{3}{c}{ Jam sample } \\
\cline { 2 - 4 } composition (\%) & $\mathrm{M}$ & $\mathrm{PC}$ & $\mathrm{CP}$ \\
\hline Color & $8.1 \pm 0.738^{\mathrm{ab}}$ & $8.8 \pm 0.422^{\mathrm{a}}$ & $7.7 \pm 0.483^{\mathrm{b}}$ \\
Taste & $8.2 \pm 0.632^{\mathrm{ab}}$ & $8.7 \pm 0.483^{\mathrm{a}}$ & $7.9 \pm 0.738^{\mathrm{b}}$ \\
Texture & $7.6 \pm 0.516^{\mathrm{a}}$ & $7.3 \pm 0.483^{\mathrm{ab}}$ & $6.9 \pm 0.738^{\mathrm{b}}$ \\
Flavor & $8.4 \pm 0.699^{\mathrm{ab}}$ & $8.5 \pm 0.707^{\mathrm{a}}$ & $7.8 \pm 0.632^{\mathrm{b}}$ \\
Overall acceptability & $8.1 \pm 0.738^{\mathrm{ab}}$ & $8.5 \pm 0.527^{\mathrm{a}}$ & $7.71 \pm 0.483^{\mathrm{b}}$ \\
\hline
\end{tabular}

Values are expressed as mean \pm standard deviation of three replicates. Values with the same superscript within row indicates no significant difference $(\mathrm{p}>0.05)$.

Sample PC secured the highest scores in case of color ( $8.8 \pm 0.422)$, taste $(8.7 \pm 0.483)$, flavor $(8.5 \pm 0.707)$ and overall acceptability $(8.5 \pm 0.527)$, while in case of texture sample $M$ showed the highest score (7.6 \pm 0.516$)$. On the contrary, sample CP showed the lowest scores for color (7.7 \pm 0.483$)$, flavor ( $7.8 \pm 0.632)$, taste $(7.9 \pm 0.738)$, texture $(6.9 \pm 0.738)$ and overall acceptability (7.71 \pm 0.483$)$.

The evaluation is in accordance with the reports of Sindumathi and Amutha (2014) in case of coconut-based jam, Rajkumar et al. (2018) in case of rose petal jam and Gagan and Aditya (2018) for rose petal jam.

\subsection{Yeast and mold count}

The results of yeast and mold counts are depicted in Table 5. Plate counts of $2.6 \times 10^{2}, 2 \times 10^{2}$ and $2.3 \times 10^{2}$ were found in case of samples $\mathrm{M}, \mathrm{PC}$ and $\mathrm{CP}$ respectively packed in plastic container stored under room temperature. It was noticed that colony forming units were reduced with the increasing of samples acidity level. Inam et al. (2012) and Brandão et al. (2018) also found an opposite relation with samples acidity to the mold colony forming units.

Table 5. Yeast and mold count of jam

\begin{tabular}{ccccc}
\hline \multirow{2}{*}{$\begin{array}{c}\text { Jam } \\
\text { Samples }\end{array}$} & \multicolumn{3}{c}{ Yeast and Mold Count (CFU/mL) } \\
\cline { 2 - 5 } & $\begin{array}{c}\text { Rlass } \\
\text { Container }\end{array}$ & $\begin{array}{c}\text { Plastic } \\
\text { Container }\end{array}$ & $\begin{array}{c}\text { Glass } \\
\text { Container }\end{array}$ & $\begin{array}{c}\text { Plastic } \\
\text { Container }\end{array}$ \\
\cline { 2 - 5 } M & 0 & $2.6 \times 10^{2}$ & 0 & 0 \\
PC & 0 & $2 \times 10^{2}$ & 0 & 0 \\
CP & 0 & $2.3 \times 10^{2}$ & 0 & 0 \\
\hline
\end{tabular}

\section{Conclusion}

The prepared mixed fruit jam samples with different fruit concentrations showed excellent taste, high nutritive values and good sensory acceptability. Sample with pineapple and coconut pulp in 3:1 ratio showed better result compared to others. Storage stability analysis presented a gradual increase in TSS, acidity and reducing sugar, where increase rate was relatively slower in case of refrigerated temperature storage compared to room temperature storage. The $\mathrm{pH}$ of the samples declined with the storage time extension. The samples found negative for yeast and mold count except samples packed in plastic containers stored under room temperature. Therefore, further research is necessary in this field with compositional diversification and storage study.

\section{Conflict of interest}

The authors declare no conflict of interest.

\section{Acknowledgements}

The authors are highly grateful to officers and staffs of the Department of Agro Product Processing Technology, Jashore University of Science and Technology, Jashore-7408, Bangladesh for providing the instrumentation and other resources to carry out the study.

\section{References}

AOAC. (2016). Official methods of analysis. Association of Official Analytical Chemists. $20^{\text {th }}$ ed. Washington, D.C., USA: AOAC.

Ackom, N.B. and Tano-Debrah, K. (2012). Processing Pineapple Pulp into Dietary Fibre Supplement. African Journal of Food, Agriculture, Nutrition and Development, 2(6), 6823-6834.

Amarasiri, W.A. and Dissanayake, A.S. (2006). Coconut fats. The Ceylon Medical Journal. 51(2), 47-51. https://doi.org/10.4038/cmj.v51i2.1351

Anuradha, D., Arya, Asha, Bhalerao, Jaishree G. and 
Shinde R.S. (2017). Development of value-added papaya and pineapple jams. Food Science Research Journal, 8(1), 76-82. https://doi.org/10.15740/HAS/ FSRJ/8.1/76-82

Baker, R.A., Berry, N., Hui, Y.H. and Barrett, D.M. (2005). Food Preserves and Jams: Processing Fruits. $2^{\text {nd }}$ ed., p. $113-125$. USA: CRC Press LLC.

Begum, S., Das, P.C. and Karmoker, P. (2018). Processing of mixed fruit juice from mango, orange and pineapple. Fundamental and Applied Agriculture, 3(2), 440-445. https://doi.org/10.5455/ faa.289995

Brandão, T.M., do Carmo, E.L., Elias, H., de Carvalho, E., Borges, S.V. and Martins, G. (2018). Physicochemical and Microbiological Quality of Dietetic Functional Mixed Cerrado Fruit Jam during Storage. The Scientific World Journal, 2018, 2878215. https://doi.org/10.1155/2018/2878215

Coppens, E.G., Leal, F. and Rohrbach, K.G. (2003). The Pineapple: Botany, Production, and Uses. Wallingford. $2^{\text {nd }}$ ed., p. 21. UK: CABI Publishing.

Eke-Ejiofor, J. and Owuno, F. (2013). The Physicochemical and Sensory Properties of Jackfruit (Artocarpus heterophilus) Jam. International Journal of Nutrition and Food Sciences, 2(3), 149152. https://doi.org/10.11648/j.ijnfs.20130203.19

Gagan, T. and Aditya, B. (2018). Development of Herbal Jelly (with Hibiscus Rosa sinensis and Rose petals). Journal of Medicinal Plants Studies, 6(6), 30-32.

Gałkowska, D., Fortuna, T. and Zagórska, W.P. (2010). Physicochemical quality of selected strawberry jams with fructose. Potravinarstvo Slovak Journal of Food Sciences, 4(2), 22-24. https:// doi.org/10.5219/46.

Gomez K.A. and Gomez, A.A. (1984). Statistical Procedures for Agricultural Research, Second edition. New York, USA: John Wiley and Sons.

Hussain, I. and Shakir, I. (2010). Chemical and organoleptic characteristics of jam prepared from indigenous varieties of apricot and apple. World Journal of Diary and Food Sciences, 5(1), 73-78.

Inam, A.K.M.S., Hossain, M.M., Siddiqui, A.A. and Easdani, M. (2012). Studies on the Development of Mixed Fruit Marmalade. Journal of Environmental Science and Natural Resources, 5(2), 315 - 322. https://doi.org/10.3329/jesnr.v5i2.14836

Javanmard, M. and Endan, J.A. (2010). Survey on Rheological Properties of Fruit Jams. International Journal of Chemical Engineering and Applications, 1(1), 31-37. https://doi.org/10.7763/ IJCEA.2010.V1.6

Kumar, M., Nataraj, S., Jayaprahash, S.S.N. and Baua,
A.S. (2007). Development and evaluation of retort pouch processed ready to eat coconut kheer. Indian coconut journal, 30(8), 2-6.

Mahdi, Z.E., Ashraf. M. Sharoba, El-Desouky, A.E. and Bahlol, H.E. (2019). Chemical, Sensory and Microbiological Assessment of Some Local and Imported Jam in the Egyptian Market. Annals of Agricultural Science Moshtohor Journal, 57(2), 405 - 418. https://doi.org/10.21608/assjm.2019.44299

Monika, Y., Akatar H.H.K., Binod, K.B. and Meghna J. (2018). Comparative study of physico-chemical property in different brands of jam, honey and jelly. Journal of Pharmacognosy and Phytochemistry, 7 (5), 2186-2191.

Naeem, M.M.N., Fairulnizal, M.N., Norhayati, M.K., Zaiton, A., Norliza, A.H., Syuriahti Wan, W.Z., Azerulazree, M.J., Aswir, A.R. and Rusidah, S. (2017). The nutritional composition of fruit jams in the Malaysian market. Journal of the Saudi Society of Agricultural Sciences, 16(1), 89-96. https:// doi.org/10.1016/j.jssas.2015.03.002

Nindo, C.I., Tang. J., Powers, J.R. and Singh, P. (2005). Viscosity of blueberry and raspberry juices for processing applications. Journal of Food Engineering, 69(3), 343-350. https:// doi.org/10.1016/j.jfoodeng.2004.08.025

Olugbenga, O.A., Grace, O.O., Modupe, E.O. and Funmilayo, G.O. (2018). Functional Jam Production from Blends of Banana, Pineapple and Watermelon Pulp. International Journal of Food Science and Biotechnology, 3(1), 7-14. https://doi.org/10.11648/ j.ijfsb.20180301.12

Othman, O.C. (2011). Physicochemical Characteristics and Levels of Inorganic Elements Off-vine Ripened Pineapple (Ananas comosus L.) fruits of Dar es Salaam, Tanzania KIST. Journal of Science and Technology, 1(1), 23 - 30.

Patel, N.V., Naik, A.G. and Senapati, A.K. (2015). Quality evaluation and storage study of banana pineapple blended jam. International Journal of Food Quality and Safety, 1, 45-51.

Pearson, D. (1970). The chemical analysis of foods. $6^{\text {th }}$ ed., p. 76-89. London: A. Churchill.

Rajkumar, J., Mahawer, L.N., Bairwa, H.L., Meena, R.H., Pilania, S. and Singh, M. (2018). Sensory evaluation and microbial analysis of rose petal jam. Journal of Pharmacognosy and Phytochemistry, 7 (5), 617-620.

Saka, J., Rapp, I., Akinnifesi, F., Ndolo, V. and Mhango, J. (2007). Physicochemical and Organoleptic characteristics of Uapacakirkiana, Strychnoscocculoides, Adansoniadigitata and 
Mangiferiaindica fruit products. International Journal of Food Science and Technology, 42(7), 836 -841. https://doi.org/10.11648/j.ijfsb.20180301.12

Satkar, K., Jayashree, A. and Muralidharan. (2012). Value added products from coconut: Coconut for health \& wealth. Indian Coconut Journal, 54(8), 2428.

Sindumathi, G. and Amutha, S. (2014). Processing and quality evaluation of coconut-based jam. IOSR Journal of Environmental Science, Toxicology and Food Technology, 8(1), 10-14. https:// doi.org/10.9790/2402-08111014

Suutarinen, M. (2002). Effects of pre-freezing treatments on the structure of strawberries and jams. Finland: Helsinki University of Technology, PhD. Dissertation.

Unaegbu, M., Engwa, G.A. and Abaa, Q. (2016). Heavy metal, nutrient and antioxidant status of selected fruit samples sold in Enugu, Nigeria. International journal of Food Contamination, 3, 7. https:// doi.org/10.1186/s40550-016-0031-9

Vidhya, R. and Narain, A. (2011). Development of preserved products using under exploited fruits, Wood Apple. American Journal of Food Technology, 6(4), 279-288. https://doi.org/10.3923/ ajft.2011.279.288 